University of Nebraska - Lincoln

DigitalCommons@University of Nebraska - Lincoln

\title{
The Influence of Oscillating Dietary Protein Concentrations on Finishing Cattle. II. Nutrient Retention and Ammonia Emissions
}

\author{
S. L. Archibeque \\ USDA-ARS, US Meat Animal Research Center, Clay Center, NE
}

H. C. Freetly

USDA-ARS, harvey.freetly@ars.usda.gov

N. A. Cole

USDA-ARS, Conservation and Production Research Laboratory, Bushland, TX

Calvin Ferrell

University of Nebraska-Lincoln, cferrell2@unl.edu

Follow this and additional works at: https://digitalcommons.unl.edu/usdaarsfacpub

Part of the Agricultural Science Commons

Archibeque, S. L.; Freetly, H. C.; Cole, N. A.; and Ferrell, Calvin, "The Influence of Oscillating Dietary Protein Concentrations on Finishing Cattle. II. Nutrient Retention and Ammonia Emissions" (2007). Publications from USDA-ARS / UNL Faculty. 235.

https://digitalcommons.unl.edu/usdaarsfacpub/235

This Article is brought to you for free and open access by the U.S. Department of Agriculture: Agricultural Research Service, Lincoln, Nebraska at DigitalCommons@University of Nebraska - Lincoln. It has been accepted for inclusion in Publications from USDA-ARS / UNL Faculty by an authorized administrator of DigitalCommons@University of Nebraska - Lincoln. 


\title{
The influence of oscillating dietary protein concentrations on finishing cattle. II. Nutrient retention and ammonia emissions ${ }^{1,2}$
}

\author{
S. L. Archibeque, ${ }^{* 3}$ H. C. Freetly, ${ }^{*}$ N. A. Cole, $\dagger$ and C. L. Ferrell ${ }^{* 4}$ \\ *USDA-ARS, US Meat Animal Research Center, Clay Center, NE 68933-0166; and \\ †USDA-ARS, Conservation and Production Research Laboratory, Bushland, TX 79106
}

\begin{abstract}
We hypothesized that oscillation of the dietary CP concentrations would improve efficiency of $\mathrm{N}$ use and reduce $\mathrm{N}$ loss to the environment. Charolaiscross steers ( $\mathrm{n}=8 ; 315 \pm 21 \mathrm{~kg}$ of $\mathrm{BW})$ were used in a replicated $4 \times 4$ Latin square design. The steers were allowed ad libitum access to the following diets: 1) $9.1 \%$ CP (low), 2) $11.8 \%$ CP (medium), 3) $13.9 \%$ CP (high), or 4) low and high oscillated on a 48-h interval on each diet (oscillating). Dry matter intake did not differ among treatments $(P=0.46)$, but $\mathrm{N}$ intake differed $(P$ $<0.01$ ) from 94 (low) to 131 (medium), 142 (high), and $133 \mathrm{~g} / \mathrm{d}$ (oscillating), as designed. Dry matter digestibility increased $(P<0.01)$ from $71.8 \%$ (low) to $75.8 \%$ (medium), $77.7 \%$ (high), and $77.5 \%$ (oscillating). Nitrogen digestibility increased $(P<0.01)$ from $62.2 \%$ (low) to $67.2 \%$ (medium) to $70.1 \%$ (high) and $70.9 \%$ (oscillating). Nitrogen retention was greater $(P<0.01)$ in steers fed oscillating $(55.0 \mathrm{~g} / \mathrm{d})$ than in the steers fed low $(34.8 \mathrm{~g} /$ d) or high $(40.2 \mathrm{~g} / \mathrm{d})$, but $\mathrm{N}$ retention of steers fed medium $(49.8 \mathrm{~g} / \mathrm{d})$ differed $(P=0.02)$ only from that of
\end{abstract}

steers fed low. Urinary urea $\mathrm{N}$ did not differ between steers fed medium $(19.5 \mathrm{~g} / \mathrm{d})$ or oscillating $(21.3 \mathrm{~g} / \mathrm{d})$ but was lowest $(P<0.01)$ for those fed low $(8.2 \mathrm{~g} / \mathrm{d})$ and greatest for those fed high $(39.2 \mathrm{~g} / \mathrm{d})$. Daily heat production $\left(\mathrm{kcal} / \mathrm{BW}^{0.75}\right)$ tended $(P=0.09)$ to be less for the steers fed low (177) than those fed medium (189), high (188), or oscillating (182). Cumulative in vitro ammonia volatilization from the manure of steers fed oscillating was lower $(P<0.01)$ for the initial $5 \mathrm{~d}$ of incubation than from manure of those fed medium, but there was no difference after $11 \mathrm{~d}$ of incubation. Additionally, there was a decrease $(P<0.01)$ in in vitro ammonia volatilization as protein concentration in the diet decreased from high to medium to low. These data indicate that oscillation of the dietary protein improved $\mathrm{N}$ retention of finishing steers compared with those in high and low $\mathrm{N}$ diets and that these changes were great enough to correspondingly alter ammonia volatilization from manure.

Key words: beef cattle, heat production, nutrient balance, protein oscillating

(C2007 American Society of Animal Science. All rights reserved.

J. Anim. Sci. 2007. 85:1496-1503

doi:10.2527/jas.2006-208

\section{INTRODUCTION}

Emissions of ammonia, as well as of other gases and particulates, to the atmosphere are a growing concern to livestock producers, the general public, and regulatory agencies. Concentrated animal feeding operations are implicated as a major contributor to these emissions.

\footnotetext{
${ }^{1}$ Mention of trade names or commercial products in this publication is solely for the purpose of providing specific information and does not imply recommendation or endorsement by the USDA.

${ }^{2}$ The author acknowledges the secretarial assistance of J. Byrkit and the technical assistance of C. Felber, C. Haussler, and K. Sorensen.

${ }^{3}$ Present address: Dept. Anim. Sci., Colorado State Univ., Ft. Collins, CO 80523-1171.

${ }^{4}$ Corresponding author: cal.ferrell@ars.usda.gov

Received April 4, 2006.

Accepted January 26, 2007.
}

Most ammonia emitted from concentrated animal feeding operations is produced from the microbial hydrolysis of urinary urea to ammonium and carbon dioxide (Mobley et al., 1995). Thus, factors that decrease urinary $\mathrm{N}$ excretion could decrease ammonia emissions (Erickson and Klopfenstein, 2001; Cole et al., 2005).

One possible means of improving $\mathrm{N}$ retention and reducing ammonia emission is by oscillating the dietary CP concentrations. Collins and Pritchard (1992) noted an improvement in $\mathrm{N}$ utilization with decreased frequency of protein supplementation to lambs. Similarly, Cole (1999) noted an increase in $\mathrm{N}$ retention in lambs by oscillating the CP concentration of the diet over 48$\mathrm{h}$ intervals. However, Ludden et al. (2002a) did not observe an improvement in $\mathrm{N}$ retention with oscillating $\mathrm{CP}$ concentrations when sheep were fed at relatively high dietary $\mathrm{CP}$ concentrations (13 to $17 \%$ ). Dietary CP (Ludden et al., 2002a) was likely in excess of needs for those lambs, such that any effect of oscillating diets on 
$\mathrm{N}$ metabolism may have been masked by the increased $\mathrm{N}$ that was excreted. Ludden et al. (2002a) also noted a decrease in overall $\mathrm{N}$ digestibility when lambs were fed oscillating $\mathrm{CP}$ diets, resulting in increased fecal relative to urinary $\mathrm{N}$.

Studies showing improved N retention with oscillation of dietary protein in finishing diets have used sheep (Cole, 1999) or mathematical models (Cole et al., 2003). To the best of our knowledge, this concept has not yet been directly tested in finishing beef cattle.

Our hypothesis was that oscillating dietary protein diets reduce ammonia emissions by reducing urinary excretion of nitrogenous compounds. Additional effects on performance characteristics and odorous compound production are described in a companion paper (Archibeque et al., 2007b).

\section{MATERIALS AND METHODS}

\section{Animals and Experimental Procedures}

The US Meat Animal Research Center Animal Care and Use Committee approved these experimental procedures. Steers ( $\mathrm{n}=8 ; 315 \pm 21 \mathrm{~kg}$ of BW), sired by Charolais bulls bred to $3 / 4$ Angus, $1 / 4$ Piedmontese dams, were weaned between 167 and $186 \mathrm{~d}$ of age and were moved to an enclosed barn $42 \mathrm{~d}$ after weaning. Steers were housed in individual stalls $(87 \mathrm{~cm} \times 214 \mathrm{~cm})$ with automatic, individual water cups and were adapted to close human contact over $4 \mathrm{wk}$. During this time, the steers were also adapted to the medium-protein finishing ration (Table 1) in 4 step-up periods of $6 \mathrm{~d}$ each, wherein $25 \%$ of the growing ration was sequentially replaced with the finishing ration. The steers were fed the medium diet for 1 wk before initiation of the study. Steers were fed once daily throughout the study and allowed ad libitum access to diets by offering $110 \%$ of intake on the previous day. The dietary treatments consisted of a low-protein diet that was deficient in MP (NRC, 2000), a high-protein diet that was excessive in MP, and medium that was adequate in $\mathrm{MP}$ and had a $\mathrm{N}$ concentration that was near the mean of low and high (Table 1). The fourth dietary treatment was the oscillating diet that consisted of alternating feeding of low and high at 48-h intervals (low for $2 \mathrm{~d}$, followed by high for $2 \mathrm{~d}$ ).

After the 4-wk adaptation, the steers were stratified by BW and assigned to 1 of 2 Latin square replicates. Steers were adapted to each diet for at least $13 \mathrm{~d}$, but no more than $14 \mathrm{~d}$, and during this initial adaptation period, the steers were allowed to exercise in an open, dirt pen at least 3 times weekly. Total collections of urine, feces, and orts were conducted for $8 \mathrm{~d}$ after the adaptation to the respective diet. Feed was sampled daily during the $8 \mathrm{~d}$ of sample collection. Urine collection from each steer was accomplished using a urine collection harness and was aspirated into a polypropylene jug under vacuum. Each urine jug contained $100 \mathrm{~mL}$ of 6 $M \mathrm{HCl}$ to prevent ammonia losses. Feces were collected using a canvas bag attached to a harness. Feces and urine were collected daily, weighed, and an aliquot (5\% of daily output) was pooled within steer and frozen $\left(\leq-17^{\circ} \mathrm{C}\right)$ for subsequent analysis. Urine $\mathrm{pH}$ was measured with $\mathrm{pH}$-sensitive paper before collection of aliquots to assure a $\mathrm{pH}<4$.

Composited feed, ort, and fecal samples were weighed and dried in a forced air oven $\left(55^{\circ} \mathrm{C}\right)$. Dry samples were weighed, then ground with a Wiley Mill (Arthur Thomas Co., Philadelphia, PA) fitted with a 1-mm screen. A subsample of feed, orts, and feces were dried at $70^{\circ} \mathrm{C}$ for determination of lab DM. Concentrations of N (Leco CN2000 carbon/nitrogen analyzer, Leco Corporation, St. Joseph, MI) and $\mathrm{P}\left(\mathrm{HNO}_{3}\right.$ digestion and subsequent color development using the Fiske chemical method; Fiske and Subbarow, 1925) were determined in feed, orts, partly dried feces, and urine. Urinary urea $\mathrm{N}$ was measured (Marsh et al., 1965) using a Technicon Autoanalyzer (Method \#339-01; Technicon Autoanalyzer System, Tarrytown, NY). Gross energy (bomb calorimetry) was determined for feed, orts, and feces. Urinary GE was estimated from urinary $\mathrm{N}$, as described by Blaxter (1962).

Immediately after each balance trial, $\mathrm{O}_{2}, \mathrm{CO}_{2}$, and $\mathrm{CH}_{4}$ exchanges were measured by indirect calorimetry for $6 \mathrm{~h}$, and heat production was calculated (Eisemann and Nienaber, 1990). Fresh feed and water were placed in the head-box calorimeters before the indirect calorimetry measurement to allow steers ad libitum access to their respective diets and water during the measurement.

\section{In Vitro Ammonia Emissions}

Composite samples of the feces that were collected from the steers throughout each of the balance trial collections were used for in vitro ammonia emission assays. Urine for the in vitro assay was collected by a urine collection harness and aspirated into polypropylene jugs, without acid, during the indirect calorimetry measurement, and subsequently was frozen until used.

The in vitro ammonia emission system has been described previously (Shi et al., 2001; Cole et al., 2005). Briefly, the system was composed of 48 sealed polyethylene chambers $(20 \mathrm{~cm} \times 20 \mathrm{~cm} \times 12 \mathrm{~cm})$, each attached to 2 ammonia-trapping bottles containing $100 \mathrm{~mL}$ of 0.9 $M$ sulfuric acid at room temperature $\left(\sim 24^{\circ} \mathrm{C}\right)$. A vacuum system pulled air through the chambers and ammonia traps at a rate of approximately $3 \mathrm{~L} / \mathrm{min}$. Each chamber contained 1,550 g of screened soil (Pullman clay loam) and the feces and urine excretion of 1 steer (2 chambers/ steer). Soil had a pH of 7.68, was 91.7\% DM (SEM = $0.36)$, and contained $0.10 \% \mathrm{~N}(\mathrm{SEM}=0.0011), 1.69 \% \mathrm{C}$ $(\mathrm{SEM}=0.005), 24 \mathrm{ppm}$ (ammonia + ammonium $)-\mathrm{N}$ $\left(\mathbf{N H}_{\mathbf{x}}-\mathbf{N} ; \mathrm{SEM}=0.06\right)$, and $53 \mathrm{ppm}$ (nitrate + nitrite)-N $\left(\mathbf{N O}_{\mathbf{x}}-\mathbf{N} ; \mathrm{SEM}=2.2\right)$, all on a DM basis. The quantity of urine and feces added to each chamber was equal to $1 \%$ of the daily excretion by the steer during the nutrient balance trial. Because a total of 2 in vitro ammonia emission runs were required, 4 chambers containing a 
Table 1. Dry matter and chemical composition of the experimental diets

\begin{tabular}{|c|c|c|c|}
\hline \multirow[b]{2}{*}{ Item } & \multicolumn{3}{|c|}{ Diet } \\
\hline & Low & Medium & High \\
\hline \multicolumn{4}{|l|}{ Ingredient, $\%$ of $\mathrm{DM}$} \\
\hline Corn silage & 10.00 & 10.00 & 10.00 \\
\hline Dry rolled corn & 81.52 & 77.02 & 72.73 \\
\hline Soybean meal & - & 6.47 & 12.93 \\
\hline Molasses (dry) & 7.00 & 5.10 & 3.00 \\
\hline Limestone & 1.11 & 1.20 & 1.30 \\
\hline Dicalcium phosphate & 0.33 & 0.17 & 0.00 \\
\hline Trace mineral premix ${ }^{1}$ & 0.02 & 0.02 & 0.02 \\
\hline Vitamin A, D, and E premix ${ }^{2}$ & 0.01 & 0.01 & 0.01 \\
\hline Rumensin $80^{3}$ & 0.01 & 0.01 & 0.01 \\
\hline \multicolumn{4}{|l|}{ Nutrient content, DM basis } \\
\hline $\mathrm{DM}, 4 \%$ & $77.63 \pm 0.39$ & $77.45 \pm 1.15$ & $77.80 \pm 0.67$ \\
\hline $\mathrm{CP},{ }^{4} \%$ & $9.13 \pm 0.10$ & $11.75 \pm 0.52$ & $13.94 \pm 0.24$ \\
\hline $\mathrm{DIP}, 5 \%$ & 4.57 & 6.85 & 8.82 \\
\hline $\mathrm{UIP}, 5 \%$ & 4.56 & 4.90 & 5.12 \\
\hline $\mathrm{MP}, 6$ & $10.77 / 6.25$ & $11.06 / 7.01$ & $11.26 / 7.36$ \\
\hline $\mathrm{ME},{ }^{5} \mathrm{Mcal} / \mathrm{kg}$ & 3.08 & 3.08 & 3.08 \\
\hline $\mathrm{NEm},{ }^{5} \mathrm{Mcal} / \mathrm{kg}$ & 2.10 & 2.10 & 2.10 \\
\hline $\mathrm{NEg},{ }^{5} \mathrm{Mcal} / \mathrm{kg}$ & 1.43 & 1.43 & 1.43 \\
\hline $\mathrm{Ca},{ }^{5} \mathrm{~g} / \mathrm{kg}$ & 5.78 & 5.79 & 5.79 \\
\hline $\mathrm{P},{ }^{4} \mathrm{~g} / \mathrm{kg}$ & $2.60 \pm 0.18$ & $2.68 \pm 0.26$ & $2.80 \pm 0.22$ \\
\hline
\end{tabular}

${ }^{1}$ Trace mineral premix contained $13 \% \mathrm{Ca}, 12 \% \mathrm{Zn}, 8 \% \mathrm{Mn}, 10 \% \mathrm{Fe}, 1.5 \% \mathrm{Cu}, 0.2 \% \mathrm{I}$, and $0.1 \% \mathrm{Co}$.

${ }^{2}$ Vitamin A, D, and E premix contained 8,800,000 IU of vitamin A; 880,000 IU of vitamin D; and $880 \mathrm{mg}$ of vitamin E per kilogram.

${ }^{3}$ Elanco Animal Health, Greenfield, IN (17.6 mg of monensin/kg of final ration DM).

${ }^{4}$ Measured values of balance trial composites $(n=4 /$ treatment $) \pm$ SD.

${ }^{5} \mathrm{DIP}=$ degradable intake protein, UIP $=$ undegradable intake protein, calculated using tabular values (NRC, 2000).

${ }^{6}$ Calculated using level 1/level 2 estimates from the NRC (2000).

common feces and urine were included in each run to correct for run-to-run variation in ammonia emissions. Differences in temperature, atmospheric ammonia, airflow rate, or other factors may have contributed to the run-to-run variation. Two blank chambers containing soil without feces and urine were included in each run to correct for atmospheric ammonia contamination.

Acid traps were replaced with fresh traps each day for $5 \mathrm{~d}$ and then at 2-d intervals until d 11 of collection. At the conclusion of the run, the media in each chamber were thoroughly mixed, and a sample was obtained and stored frozen for later laboratory analyses.

Feces, soil, and media (soil + feces + urine mixture) samples were analyzed for DM by drying to a constant weight at $60^{\circ} \mathrm{C}$ in a forced draft oven. The $\mathrm{pH}$ of feces, soil, and media were determined by mixing $5 \mathrm{~g}$ of soil or feces with $5 \mathrm{~mL}$ of deionized water. The mixture was stirred, allowed to stand for $1 \mathrm{~min}$, and the $\mathrm{pH}$ was determined using a combination electrode. The $\mathrm{C}$ and $\mathrm{N}$ contents of soil, feces, urine, and ending media were determined using a Carbon-Nitrogen Analyzer (Vario Max CN, Elementar Americas Inc., Mt. Laurel, NJ). The $\mathrm{N}$ content of the acid traps was determined colorimetrically using a flow injection analyzer (Lachat Instruments Quick Chem FIA+800, Milwaukee, WI, Method 10-10706-2-E, 2001: USEPA, 1983, Method 351.2). Initial soil and fecal samples, and ending media samples were extracted with $2 M \mathrm{KCl}(20 \mathrm{~mL} / 2 \mathrm{~g}$ of air-dried sample) and filtered (Whatman \#42 filter paper). The $\mathrm{NH}_{\mathrm{x}}-\mathrm{N}$ content of the filtrate was determined by the phenate method (Lachat Method 12-107-06-1-A; 2001: USEPA, 1983, Method 365.34), and the $\mathrm{NO}_{\mathrm{x}}-\mathrm{N}$ content was determined by cadmium reduction (Lachat Method 12-10704-1-B; 2001: USEPA, 1983, Method 353.2) using the flow injection analyzer.

\section{Statistical Analysis}

The GLM procedure (SAS Inst. Inc., Cary, NC) was used for statistical analysis of the data. The model for nutrient and energy balance measures included the independent variables (replication, steer within replication, period within replication, and treatment). Treatment effects were considered significant at $P<0.05$. A tendency for treatment to elicit a response was noted when $P$ $<0.10$. Least squares means were separated using a protected Student's $t$-test.

Data for cumulative ammonia $\mathrm{N}$ emissions were analyzed as a replicated $4 \times 4$ Latin square, with repeated measures by day, and with AR(1) covariance using the MIXED procedure of SAS. The model included the independent variables (replication, steer within replication, period within replication, treatment, day, and treatment $x$ day). Least squares means were compared using a protected Student's $t$-test if a significant $(P<0.05) F$-test was obtained. Additionally, regressions of cumulative 


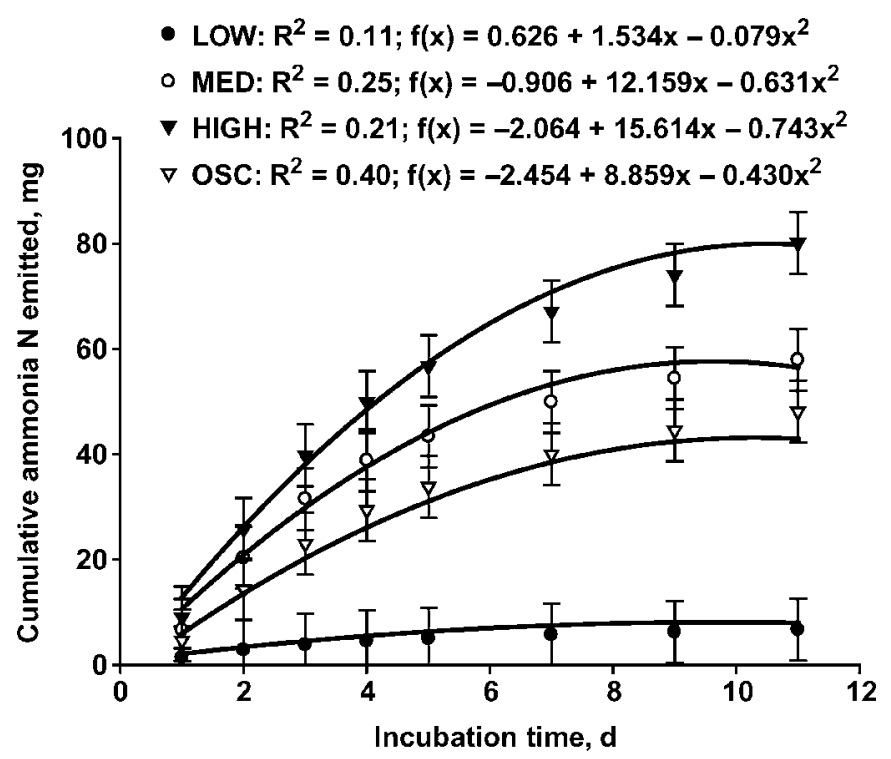

Figure 1. Cumulative emission of ammonia $\mathrm{N}$ from manure of steers fed diets with low, medium, high, or oscillating dietary protein. Error bars indicate SEM when data were analyzed as repeated measures. Lines indicate regressions for each treatment as calculated from the raw data.

ammonia emissions over $11 \mathrm{~d}$ were calculated for each of the treatment groups using the REG procedure of SAS. The quadratic term was included because, with the exception of the low treatment, it was determined to be different $(P<0.01)$ from 0 . The least squares means are reported along with the regressions in Figure 1.

\section{RESULTS}

There were 4 occurrences when a 7-d (rather than 8 d) total collection of feces and urine was conducted because of a failure in the excreta collection system on the first day of collection. These collections involved 1 steer receiving low and 3 steers receiving medium.

This study was designed to provide a linear increase in dietary $\mathrm{N}$ from subadequate (low) to adequate (medium) and excessive (high) levels. This design was intended to provide controls at these levels to determine if the oscillating differed from medium and the expected changes associated with a linear change in dietary N. However, due to variability in voluntary DMI (Table 2), daily $\mathrm{N}$ intake was not different $(P \geq 0.10)$ among steers fed medium (131.3 g), high (142.5 g), or oscillating (133.1 $\mathrm{g})$, but was less $(P=0.001)$ in steers fed low $(94.3 \mathrm{~g})$. Daily fecal $\mathrm{N}$ did not differ between steers fed high or medium, but was reduced when steers were fed oscillating $(P=0.05)$ or low $(P=0.01)$. Daily total urinary $\mathrm{N}$ was greatest $(P=0.01)$ in the steers fed high, intermediate in steers fed medium or oscillating, and least in steers fed low. Urinary urea $\mathrm{N}$ excretion was greatest $(P<0.01)$ in the steers fed high, intermediate in steers fed either medium or oscillating, and least in steers fed low. Simi- larly, urinary urea $\mathrm{N}$ as a percentage of total urinary $\mathrm{N}$ increased $(P=0.001)$ from $33.5 \%$ in steers fed low to $48.4 \%$ (medium) and $51.5 \%$ (oscillating) and was greatest (64.3\%) for high.

As the dietary $\mathrm{N}$ concentration increased, there was a subsequent increase $(P=0.01)$ in apparent $\mathrm{N}$ digested, from 58.7 (low), to 88.6 (medium), to $99.9 \mathrm{~g} / \mathrm{d}$ (high) with the steers fed oscillating digesting $94.7 \mathrm{~g} / \mathrm{d}$. These differences in $\mathrm{N}$ digested, along with the limited differences in $\mathrm{N}$ intake, yielded a greater $(P=0.001)$ apparent $\mathrm{N}$ digestibility in the steers fed high $(70.1 \%)$ or oscillating (70.8\%) than those fed medium $(67.2 \%)$ or low $(62.2 \%$; Table 2).

Nitrogen retention $(\mathrm{g} / \mathrm{d})$ was greater $(P=0.02)$ in the steers fed oscillating compared with steers fed low or high (Table 2). Although medium did not differ in $\mathrm{N}$ intake from oscillating, $\mathrm{N}$ retention of steers fed medium differed only from the steers fed low, but not high.

Due to differences in the amounts and composition of excreta produced by steers on the 4 dietary treatments, there were subsequent differences in the amounts of feces and urine, and consequently different amounts of fecal and urinary $\mathrm{N}$ added to the in vitro ammonia emission chambers for each of the 4 treatments (Table 3). Although the amount of fecal $\mathrm{C}$ added to the ammonia emission chambers did not differ $(P=0.35)$ among treatments, the total amount of $\mathrm{N}$ added to the chambers for the low treatment was less than for the medium, high, or oscillating treatments. Additionally, urinary $\mathrm{pH}$ tended to increase $(P=0.06)$ from a low of 8.10 in the low treatment to 8.84 in the high treatment, whereas there was no difference between the urinary $\mathrm{pH}$ of the medium (8.66) and oscillating (8.36) treatments. Following the $11 \mathrm{~d}$ incubation, there were similar alterations in the final composition in the manure soil mixture. The final $\mathrm{pH}$ was greater $(P=0.04)$ in the high treatment than in the low treatment, whereas there was no difference between the final $\mathrm{pH}$ of the medium and oscillating treatments. Ultimately, this led to an increase (Figure 1 ; treatment $\times$ day, $P<0.001$ ) in the cumulative amount of ammonia released from the chamber as dietary CP increased from low to medium and high. The cumulative ammonia emitted from the oscillating treatment was numerically lower than the medium treatment throughout the entire incubation, which was reflected by a lower rate of ammonia release from the chamber, as estimated by regression using the actual measured values over this 11-d period (Figure 1). The percentage of urinary $\mathrm{N}$ added to the chambers that was accounted for by cumulative ammonia volatilization over $11 \mathrm{~d}$ was lower $(P<0.001)$ for the low treatment $(2.38 \%)$ than for the medium $(8.01 \%)$, high $(8.10 \%)$, or oscillating $(6.73 \%)$ treatments (data not shown).

With current environmental concerns and the potential for animal manure to be used as a fertilizer for crops, we also assessed $\mathrm{P}$ digestion and retention and its relationship to $\mathrm{N}$ in manure (Table 2). Although there were no differences in $\mathrm{P}$ intake among the treatments $(P=0.17)$, there was a tendency for the steers fed me- 
Table 2. Nutrient intake, digestion, and retention in steers fed low, medium, high, or oscillating dietary protein ${ }^{1}$

\begin{tabular}{|c|c|c|c|c|c|c|}
\hline \multirow[b]{2}{*}{ Item } & \multicolumn{4}{|c|}{ Treatment } & \multirow[b]{2}{*}{ SEM } & \multirow[b]{2}{*}{$P$-value } \\
\hline & Low & Medium & High & Oscillating & & \\
\hline DMI, g/d & 6,439 & 6,914 & 6,494 & 6,555 & 223 & 0.46 \\
\hline DM digestibility, \% & $71.8^{\mathrm{a}}$ & $75.8^{\mathrm{b}}$ & $77.7^{\mathrm{b}}$ & $77.5^{\mathrm{b}}$ & 0.73 & 0.01 \\
\hline \multicolumn{7}{|l|}{ Nitrogen } \\
\hline $\mathrm{N}$ intake, $\mathrm{g} / \mathrm{d}$ & $94.3^{\mathrm{a}}$ & $131.3^{\mathrm{b}}$ & $142.5^{\mathrm{b}}$ & $133.1^{\mathrm{b}}$ & 4.3 & 0.01 \\
\hline Feces N, g/d & $35.6^{\mathrm{a}}$ & $42.7^{\mathrm{b}}$ & $42.6^{\mathrm{b}}$ & $38.4^{\mathrm{a}}$ & 1.5 & 0.02 \\
\hline Urine $\mathrm{N}, \mathrm{g} / \mathrm{d}$ & $23.9^{c}$ & $38.8^{\mathrm{a}}$ & $59.6^{\mathrm{b}}$ & $39.7^{\mathrm{a}}$ & 3.1 & 0.01 \\
\hline Urine urea $\mathrm{N}, \mathrm{g} / \mathrm{d}$ & $8.2^{\mathrm{c}}$ & $19.6^{\mathrm{a}}$ & $39.2^{\mathrm{b}}$ & $21.3^{\mathrm{a}}$ & 2.6 & 0.01 \\
\hline $\mathrm{N}$ digestibility, \% & $62.2^{\mathrm{c}}$ & $67.2^{\mathrm{a}}$ & $70.1^{\mathrm{b}}$ & $70.8^{\mathrm{b}}$ & 0.83 & 0.01 \\
\hline $\mathrm{N}$ retained, g/d & $34.8^{\mathrm{c}}$ & $49.8^{\mathrm{ab}}$ & $40.2^{\mathrm{ac}}$ & $55.0^{\mathrm{b}}$ & 4.0 & 0.02 \\
\hline \multicolumn{7}{|l|}{ Phosphorus } \\
\hline $\mathrm{P}$ intake, $\mathrm{g} / \mathrm{d}$ & 17.5 & 20.2 & 18.4 & 17.9 & 0.9 & 0.17 \\
\hline Feces P, g/d & 8.09 & 7.70 & 7.61 & 8.17 & 0.32 & 0.52 \\
\hline Urine $\mathrm{P}, \mathrm{g} / \mathrm{d}$ & 4.59 & 4.09 & 3.38 & 3.97 & 0.46 & 0.35 \\
\hline $\mathrm{P}$ digestibility, \% & 53.3 & 61.9 & 57.0 & 54.3 & 2.5 & 0.17 \\
\hline $\mathrm{P}$ retained, g/d & 4.78 & 8.44 & 7.42 & 5.77 & 1.03 & 0.10 \\
\hline Manure N:P3 & $4.71^{\mathrm{b}}$ & $6.92^{\mathrm{a}}$ & $9.57^{\mathrm{c}}$ & $6.46^{\mathrm{a}}$ & 0.48 & 0.01 \\
\hline
\end{tabular}

dium to digest $(P=0.08)$ and retain more $(P=0.10) \mathrm{P}$ than the steers fed low. The relationship between $\mathrm{N}$ and $\mathrm{P}$ in manure is of importance to the value of manure as a fertilizer. The $\mathrm{N}$ :P ratio was decreased $(P<0.001)$ from 9.57 in the high-fed steers to 6.92 in the medium-fed steers, 6.46 in the oscillating-fed steers, and 4.71 in the low-fed steers.

Energy metabolism components also differed among the dietary treatments (Table 4). Although there was no difference $(P=0.73)$ in intake energy, fecal energy of steers fed oscillating tended $(P=0.10)$ to be lower than that of steers fed low. As expected, urinary energy, calculated from urinary $\mathrm{N}$, increased $(P<0.001)$ from 0.38 $\mathrm{Mcal} / \mathrm{d}$ in steers fed low to $0.62 \mathrm{Mcal} / \mathrm{d}$ in the mediumfed steers, $0.63 \mathrm{Mcal} / \mathrm{d}$ in the oscillating-fed steers, and $0.95 \mathrm{Mcal} / \mathrm{d}$ in the steers fed high. Gaseous $(P=0.73)$ and retained $(P=0.54)$ energy did not differ among treatments, but heat production was less $(P=0.02)$ for the steers fed low than for those fed medium or oscillating. Additionally, although there were no differences in

Table 3. Nutrient additions to in vitro ammonia emission chambers and final manure + soil composition from steers fed low, medium, high, or oscillating dietary protein ${ }^{1}$

\begin{tabular}{|c|c|c|c|c|c|c|}
\hline Item & \multicolumn{4}{|c|}{ Treatment } & SEM & $P$-value ${ }^{2}$ \\
\hline Feces added, g & $76.5^{\mathrm{a}}$ & $70.4^{\mathrm{a}}$ & $59.7^{\mathrm{b}}$ & $61.5^{\mathrm{b}}$ & 3.14 & 0.01 \\
\hline Fecal $\mathrm{C}$ added, $\mathrm{mg}$ & 8,271 & 7,364 & 7,420 & 7,080 & 473 & 0.35 \\
\hline Fecal $\mathrm{N}$ added, mg & $371^{\mathrm{a}}$ & $440^{\mathrm{b}}$ & $448^{\mathrm{b}}$ & $407^{\mathrm{ab}}$ & 15 & 0.03 \\
\hline Urinary $\mathrm{N}$ added, mg & $301^{\mathrm{a}}$ & $657^{\mathrm{b}}$ & $829^{b}$ & $723^{\mathrm{b}}$ & 74 & 0.01 \\
\hline \multicolumn{7}{|c|}{ Composition of manure/soil mixture at conclusion of 11-d run } \\
\hline $\mathrm{pH}$ & $6.84^{\mathrm{a}}$ & $7.05^{\mathrm{ab}}$ & $7.18^{\mathrm{b}}$ & $7.00^{\mathrm{ab}}$ & 0.06 & 0.04 \\
\hline $\mathrm{N}, \mathrm{mg} / \mathrm{kg}$ & $149^{\mathrm{a}}$ & $183^{\mathrm{b}}$ & $218^{\mathrm{c}}$ & $185^{\mathrm{b}}$ & 4.0 & 0.01 \\
\hline $\mathrm{C}, \mathrm{mg} / \mathrm{kg}$ & $1,270^{\mathrm{a}}$ & $1,300^{\mathrm{a}}$ & $1,610^{\mathrm{b}}$ & $1,340^{\mathrm{a}}$ & 38 & 0.05 \\
\hline $\mathrm{NHx}-\mathrm{N},{ }^{3} \mathrm{mg}$ & $45^{\mathrm{a}}$ & $216^{\mathrm{b}}$ & $359^{\mathrm{c}}$ & $238^{\mathrm{b}}$ & 26.4 & 0.02 \\
\hline NOx-N, ${ }^{4} \mathrm{mg}$ & $189^{\mathrm{a}}$ & $317^{\mathrm{b}, \mathrm{c}}$ & $339^{\mathrm{c}}$ & $311^{\mathrm{b}}$ & 9.8 & 0.01 \\
\hline
\end{tabular}

${ }^{a-c}$ Least squares means within a row without a common superscript differ $(P<0.05)$.

${ }^{1}$ Overall means, $\mathrm{n}=8 /$ treatment.

${ }^{2}$ Probability that dietary treatments do not differ.

${ }^{3} \mathrm{NHx}-\mathrm{N}=$ (ammonia + ammonium) $-\mathrm{N}$.

${ }^{4} \mathrm{NOx}-\mathrm{N}=($ nitrate + nitrite $)-\mathrm{N}$. 
Table 4. Energy constituents for steers fed low, medium, high, or oscillating dietary protein $^{1}$

\begin{tabular}{|c|c|c|c|c|c|c|}
\hline \multirow[b]{2}{*}{ Item } & \multicolumn{4}{|c|}{ Treatment } & \multirow[b]{2}{*}{ SEM } & \multirow[b]{2}{*}{$P$-value ${ }^{2}$} \\
\hline & Low & Medium & High & Oscillating & & \\
\hline Intake energy, Mcal/d & 28.74 & 30.32 & 29.06 & 29.23 & 1.03 & 0.73 \\
\hline Fecal energy, Mcal/d & 7.79 & 7.47 & 6.75 & 6.64 & 0.34 & 0.10 \\
\hline Urinary energy, Mcal/d & $0.38^{\mathrm{a}}$ & $0.62^{\mathrm{b}}$ & $0.95^{c}$ & $0.63^{b}$ & 0.05 & 0.01 \\
\hline Gaseous energy, Mcal/d & 0.88 & 1.03 & 1.03 & 0.99 & 0.11 & 0.73 \\
\hline Heat production, Mcal/d & $14.46^{\mathrm{a}}$ & $15.63^{\mathrm{b}}$ & $15.53^{\mathrm{b}}$ & $15.03^{\mathrm{ab}}$ & 0.25 & 0.02 \\
\hline Retained energy, Mcal/d & 5.23 & 5.58 & 4.80 & 5.95 & 0.75 & 0.54 \\
\hline $\mathrm{DE}, \mathrm{Mcal} / \mathrm{d}$ & 20.95 & 22.85 & 22.31 & 22.59 & 0.75 & 0.32 \\
\hline ME, Mcal/d & 19.69 & 21.21 & 20.33 & 20.97 & 0.78 & 0.53 \\
\hline DE, Mcal/kg & $3.25^{\mathrm{a}}$ & $3.30^{\mathrm{a}}$ & $3.44^{\mathrm{b}}$ & $3.44^{\mathrm{b}}$ & 0.03 & 0.01 \\
\hline ME, Mcal/kg & $3.05^{\mathrm{a}}$ & $3.05^{\mathrm{a}}$ & $3.13^{\mathrm{ab}}$ & $3.20^{\mathrm{b}}$ & 0.03 & 0.03 \\
\hline
\end{tabular}

the apparent $\mathrm{DE}(P=0.32)$ or $\mathrm{ME}(P=0.53)$ among treatments, there were differences in the amount of $\mathrm{DE}$ and ME per kilogram of diet consumed. Apparent DE increased $(P<0.001)$ from $3.25 \mathrm{Mcal} / \mathrm{kg}$ (low) and 3.30 $\mathrm{Mcal} / \mathrm{kg}$ (medium) to $3.44 \mathrm{Mcal} / \mathrm{kg}$ (high and oscillating). Similarly, ME increased $(P=0.03$ ) from $3.05 \mathrm{Mcal} / \mathrm{kg}$ (low and medium) to $3.20 \mathrm{Mcal} / \mathrm{kg}$ (oscillating), with an intermediate value for the high treatment $(3.13 \mathrm{Mcal} /$ $\mathrm{kg}$ ). Gas exchanges from the indirect calorimetry (Table $5)$ indicate that the steers fed low consumed less $\mathrm{O}_{2}(P=$ $0.01)$ and produced more $\mathrm{CO}_{2}(P=0.04)$ than those fed medium or high.

\section{DISCUSSION}

Previous studies showed that oscillation of the dietary CP improved N retention of ruminants (Collins and Pritchard, 1992; Cole, 1999; Cole et al., 2003). This improvement in the retention of $\mathrm{N}$ may provide a viable means to reduce the release of $\mathrm{N}$, especially ammonia, into the environment. Cole (1999) hypothesized that the improvement in $\mathrm{N}$ retention by oscillating the dietary $\mathrm{CP}$ is due to improved recycling of $\mathrm{N}$ to the rumen as urea, stimulating an increase in total entry of urea $\mathrm{N}$ back to the gastrointestinal tract. That hypothesis is supported by results of Archibeque et al. (2007a), who observed greater transfer of urea $\mathrm{N}$ to the portal drained viscera when wethers were fed oscillating $\mathrm{CP}$ diets compared with those consuming a similar amount of daily protein at a static concentration. Increased recycling of urea to the portal drained viscera would likely lead to an increase in ammonia within the rumen, which may allow greater microbial CP synthesis in steers fed high concentrate diets (Devant et al., 2001). It is also worthy of note that although the weighted average of the low and high treatments would equate to $11.5 \% \mathrm{CP}$, steers fed oscillating consumed, on average, $12.7 \% \mathrm{CP}$. This may be a result of steers fed the oscillating diet selecting for a greater intake when fed high than when fed low, which may have also influenced the retention of $\mathrm{N}$.

Typical feedyard finishing diets for beef cattle contain approximately 13 to $13.5 \% \mathrm{CP}$ and contain 0.5 to $1.0 \%$ urea to provide adequate ruminally degradable intake protein (Galyean and Gleghorn, 2001). In general, as N intake increases, excretion of urinary urea $\mathrm{N}$ increases (Gueye et al., 2003; McBride et al., 2003), and as the dietary ratio of ruminally degradable:undegraded intake protein increases, urinary $\mathrm{N}$ excretion increases (Cecava and Hancock, 1994; Gueye et al., 2003; McBride et al., 2003). As this excreted $\mathrm{N}$ enters the environment, the current dogma is that most urea is rapidly hydrolyzed by endemic bacterial urease in the environment and subsequently yields ammonia. Cole et al. (2005) demonstrated a 60 to $200 \%$ increase in ammonia emission from

Table 5. Indirect calorimetry gas exchanges for steers fed low, medium, high, or oscillating dietary protein $^{1}$

\begin{tabular}{|c|c|c|c|c|c|c|}
\hline \multirow[b]{2}{*}{ Item } & \multicolumn{4}{|c|}{ Treatment } & \multirow[b]{2}{*}{ SEM } & \multirow[b]{2}{*}{$P$-value } \\
\hline & Low & Medium & High & Oscillating & & \\
\hline $\mathrm{O}_{2}$ consumed, $\mathrm{L} / \mathrm{d}$ & $2,864^{\mathrm{a}}$ & $3,086^{\mathrm{b}}$ & $3,076^{\mathrm{b}}$ & $2,965^{\mathrm{ab}}$ & 45 & 0.01 \\
\hline $\mathrm{CO}_{2}$ produced, $\mathrm{L} / \mathrm{d}$ & $2,894^{\mathrm{a}}$ & $3,176^{\mathrm{b}}$ & $3,147^{\mathrm{b}}$ & $3,061^{\mathrm{ab}}$ & 67 & 0.04 \\
\hline $\mathrm{CH}_{4}$ produced, L/d & 92 & 108 & 108 & 103 & 11 & 0.73 \\
\hline
\end{tabular}


cattle waste when protein concentration in the diet increased from 11.5 to $13 \%$. However, performance of cattle fed the same diets (Gleghorn et al., 2004) appeared to be moderately decreased when the cattle were fed the lower levels of dietary protein. Similarly, there were decreases in performance (Archibeque et al., 2007b), N retention (current study), and ammonia emissions (current study) as dietary CP was decreased below that provided by medium. Therefore, although reducing dietary $\mathrm{CP}$ will substantially reduce ammonia emissions from cattle feedlots, it may be at an undesirable cost of production, which would necessitate development of feeding methodologies that will reduce ammonia emissions without sacrificing performance.

In the companion study (Archibeque et al., 2007b) with slurries of feces, urine, soil, and water, there was more production of products associated with protein fermentation (ammonia and branched-chain VFA) for oscillating than for medium. Additionally, the manure slurries from steers fed oscillating tended to have greater production of total VFA than those from steers fed medium. The production of these acidic compounds would be expected to alter manure $\mathrm{pH}$. Although there was no significant alteration in $\mathrm{pH}$ when steers were fed oscillating instead of medium, there was a numerically lower $\mathrm{pH}$, which may have had a modest influence on ammonia volatilization from these manures. The $\mathrm{pH}$ effect would be more prominent due to the larger numerical differences in initial $\mathrm{pH}$ between the manures from the oscillatingand medium-fed steers. This early point of manure fermentation would be the time when a larger proportion of ammonium would be liberated from the urea in the urine as it interacts with the urease in the manure. Additionally, this may have coincided with the alterations in VFA production to create a more rapid drop in $\mathrm{pH}$ in the manures from the steers fed the oscillating diet, which would have effectively trapped the ammonia in the mixture before it volatilized.

In our study, only a relatively small proportion of urinary $\mathrm{N}$ applied to the system was lost as ammonia $\mathrm{N}$ (2.4 to $8.1 \%$ ) over $11 \mathrm{~d}$. These values are similar to those of Cole et al. (2005) who reported between 3.15 and $4.34 \%$ of applied urinary $\mathrm{N}$ being lost as ammonia from the same chambers under very similar conditions and length of analyses. This may be in part due to the low rate of turnover of gas within the chambers (1.2 turnovers/min). However, the loss of $\mathrm{N}$ from the in vitro system that was not accounted for by ammonia $\mathrm{N}$ release suggests that there were significant losses of $\mathrm{N}$ in forms other than ammonia $\mathrm{N}$, such as $\mathrm{N}_{2}$ and $\mathrm{NO}_{\mathrm{x}}$. This issue warrants future studies to quantify the amount and chemical entity of $\mathrm{N}$ lost from these systems. However, observed losses of urinary $\mathrm{N}$ as ammonia $\mathrm{N}$ when applied to pasture and ammonia $\mathrm{N}$ losses from manure slurries that were applied to cropland have been between 4 to $50 \%$ (Ryden et al., 1987; Jarvis et al., 1989; Lockyer and Whitehead, 1990). Additionally, Stewart (1970) observed a 25 to $90 \%$ loss of urinary $\mathrm{N}$ as ammonia $\mathrm{N}$ when applied to soil columns, whereas Kellems et al. (1979) observed a
95\% loss of urinary $\mathrm{N}$ as ammonia $\mathrm{N}$ from cattle manure slurries that did not use soil. Soil inclusion may also influence ammonia volatilization (Fenn and Kissel, 1976; Kumar and Aggarwal, 1998). This large variation in apparent volatilization of ammonia $\mathrm{N}$ among differing methodologies is likely due to a variety of factors such as air turnover rates, soil presence and composition, and other environmental factors. For example, air turnover rate increases ammonia $\mathrm{N}$ emissions from chambers or wind tunnels linearly up to 15 turnovers/min (Kissel et al., 1977; Whitehead and Raistrick, 1991). Therefore, although relative comparisons within a given method of assessing ammonia $\mathrm{N}$ emissions from a given system are likely valid, comparisons among different methodologies should be made carefully. Additionally, the production of greenhouse gasses $\left(\mathrm{CO}_{2}\right.$ and $\left.\mathrm{CH}_{4}\right)$ was not affected by oscillating dietary protein. Although there was less $\mathrm{CO}_{2}$ produced when steers were fed low, this is likely a result of lower DMI.

Although there were only limited differences in energy metabolism among the various diets, there were notable differences in the apparent $\mathrm{DE}$ concentrations of the feeds. Digestible energies were similar for high and oscillating, which were greater than low and medium. If indeed there was greater recycling of urea $\mathrm{N}$ to the rumen when steers were fed oscillating as compared with a comparable static intake of $\mathrm{CP}$, this would likely have resulted in similar ruminal ammonia status between the oscillating and high diets. Satter and Slyter (1974) noted that in vitro digestion of a corn-based concentrate diet may be affected by increasing ammonia concentration of ruminal contents. It is reasonable to assume that a similar alteration may have occurred in this study. This effect would likely not occur if the diet contains adequate degradable intake protein to provide for microbial needs. In conjunction with the adequate supply of ammonia to ruminal microbes, increased dietary $\mathrm{N}$ would reduce the recycling of urea to the rumen (Bunting et al., 1987, 1989), which could also alleviate the potential for the oscillating diet to stimulate increased recycling of urea to the rumen. These effects of greater CP diets upon ruminal ammonia concentrations and urea flux could also possibly explain why Ludden et al. (2002a,b) did not observe an improvement in $\mathrm{N}$ utilization of ruminants when oscillating CP diets were fed. This also may partially explain why any improvements in $\mathrm{N}$ retention in our study were limited. Use of oscillation of the dietary protein may have limited application in finishing systems that typically formulate diets to be in excess of the $\mathrm{N}$ needs, but as greater emphasis is placed on nutrient management, feeding oscillating $\mathrm{CP}$ diets may be a viable means of improving $\mathrm{N}$ efficiency. It is possible that improvements in response to oscillation of dietary protein diets would be greater when dietary $\mathrm{N}$ concentrations are reduced below those examined in our study.

These data support previous findings that oscillation of the dietary $\mathrm{CP}$ may slightly improve $\mathrm{N}$ retention in ruminants fed finishing diets compared with those fed similar quantities of $\mathrm{CP}$ in a static fashion. Additionally, 
these data demonstrate that the changes in manure composition of steers fed oscillating CP diets is of a great enough magnitude to then reduce overall ammonia volatilization from these manures. This technique may provide a viable option for producers who are compelled to reduce ammonia emissions from a feedlot operation without sacrificing performance.

\section{LITERATURE CITED}

Archibeque, S. L., H. C. Freetly, and C. L. Ferrell. 2007a. Net portal and hepatic flux of nutrients in growing wethers fed high-concentrate diets with oscillation of dietary protein concentrations. J. Anim. Sci. 85:997-1005.

Archibeque, S. L., D. N. Miller, H. C. Freetly, E. D. Berry, and C. L. Ferrell. 2007b. The influence of oscillating the dietary protein concentrations on finishing cattle. I. Feedlot performance and odorous compound production. J. Anim. Sci. 85:1487-1495.

Blaxter, K. L. 1962. The Energy Metabolism of Ruminants. Charles C. Thomas, Springfield, IL.

Bunting, L. D., J. A. Boling, and C. T. MacKown. 1989. Effect of dietary protein level on nitrogen metabolism in the growing bovine: I. Nitrogen recycling and intestinal protein supply in calves. J. Anim. Sci. 67:810-819.

Bunting, L. D., J. A. Boling, C. T. MacKown, and R. B. Muntifering. 1987. Effect of dietary protein level on nitrogen metabolism in lambs: Studies using ${ }^{15} \mathrm{~N}$-nitrogen. J. Anim. Sci. 64:855-867.

Cecava, M. J., and D. L. Hancock. 1994. Effects of anabolic steroids on nitrogen metabolism and growth of steers fed corn silage and corn-based diets supplemented with urea or combination of soybean meal and feather meal. J. Anim. Sci. 72:515-522.

Cole, N. A. 1999. Nitrogen retention by lambs fed oscillating dietary protein concentrations. J. Anim. Sci. 77:215-222.

Cole, N. A., R. N. Clark, R. W. Todd, C. R. Richardson, A. Gueye, L. W. Greene, and K. McBride. 2005. Influence of dietary crude protein concentration and source on potential ammonia emission from beef cattle manure. J. Anim. Sci. 83:722-731.

Cole, N. A., L. W. Greene, F. T. McCollum, T. Montgomery, and K. McBride. 2003. Influence of oscillating dietary crude protein concentration on performance, acid-base balance, and nitrogen excretion of steers. J. Anim. Sci. 81:2660-2668.

Collins, R. M., and R. H. Pritchard. 1992. Alternate day supplementation of corn stalk diets with soybean meal or corn gluten meal fed to ruminants. J. Anim. Sci. 70:3899-3908.

Devant, M., A. Ferret, S. Calsamiglia, R. Casals, and J. Gasa. 2001. Effect of nitrogen source in high-concentrate, low-protein beef cattle diets on microbial fermentation studied in vivo and in vitro. J. Anim. Sci. 79:1944-1953.

Eisemann, J. H., and J. A. Nienaber. 1990. Tissue and whole-body oxygen uptake in fed and fasted steers. Br. J. Nutr. 64:399-411.

Erickson, G. E., and T. J. Klopfenstein. 2001. Managing N inputs and the effect on losses following excretion in open-dirt feedlots in Nebraska. The Scientific World Journal 1(S2): 830-835. http:// www.thescientificworld.com Accessed December 6, 2005.

Fenn, L. B., and D. E. Kissel. 1976. The influence of cation exchange capacity and depth of incorporation on ammonia volatilization from ammonia compounds applied to calcareous soils. Soil Sci. Soc. Am. J. 40:394-398.

Fiske, C. H., and Y. Subbarow. 1925. The colorimetric determination of phosphorus. J. Biol. Chem. 66:375-400.

Galyean, M. L., and J. Gleghorn. 2001. Summary of the 2000 Texas Tech University consulting nutritionist survey. Texas Tech Uni- versity. http://www.asft.ttu.edu/burnett_center/progress_ reports/bc12.pdf Accessed June 15, 2002.

Gleghorn, J. F., N. A. Elam, M. L. Galyean, G. C. Duff, N. A. Cole, and J. D. Rivera. 2004. Effects of crude protein concentration and degradability on performance, carcass characteristics, and serum urea nitrogen concentrations in growing and finishing beef steers. J. Anim. Sci. 82:2705-2717.

Gueye, A., C. R. Richardson, J. H. Mikus, G. A. Nunnery, N. A. Cole, and L. W. Greene. 2003. Effects of dietary crude protein on serum and urine urea nitrogen in feedlot steers. J. Anim. Sci. 81(Suppl. 1):210. (Abstr.)

Jarvis, S. C., D. J. Hatch, and D. R. Lockyer. 1989. Ammonia fluxes from grazed grasslands: Annual losses from cattle production systems and their relation to nitrogen inputs. J. Agric. Sci. 113:99-108.

Kellems, R. O., J. R. Miner, and D. C. Church. 1979. Effect of ration, waste composition, and length of storage on the volatilization of ammonia, hydrogen sulfide and odors from cattle waste. J. Anim. Sci. 48:436-445.

Kissel, D. E., H. L. Brewer, and G. F. Arkin. 1977. Design and test of a field sampler for ammonia volatilization. Soil Sci. Soc. Am. J. 41:1133-1138.

Kumar, P., and R. K. Aggarwal. 1998. Interdependence of ammonia volatilization and nitrification in arid soils. Nutr. Cycling in Agroecosystems 51:201-207.

Lockyer, D. R., and D. C. Whitehead. 1990. Volatilization of ammonia from cattle urine to grassland. Soil Biol. Biochem. 22:1137-1142.

Ludden, P. A., T. L. Wechter, and B. W. Hess. 2002a. Effects of oscillating dietary protein on nutrient digestibility, nitrogen metabolism, and gastrointestinal organ mass in sheep. J. Anim. Sci. 80:3021-3026.

Ludden, P. A., T. L. Wechter, and B. W. Hess. 2002b. Effects of oscillating dietary protein on ruminal fermentation and site and extent of nutrient digestion in sheep. J. Anim. Sci. 80:3336-3346.

Marsh, W. H., B. Fingerhut, and H. Miller. 1965. Automated and manual direct methods for the determination of blood urea. Clin. Chem. 11:624-627.

McBride, K. W., L. W. Greene, N. A. Cole, F. T. McCollum, and M. L. Galyean. 2003. Nitrogen and phosphorus utilization in beef cattle fed three levels of dietary crude protein and three degradable intake protein/undegradable intake protein ratios. J. Anim. Sci. 81(Suppl. 1):73. (Abstr.)

Mobley, H. L. T., M. D. Island, and R. P. Hausinger. 1995. Molecular biology of microbial ureases. Microbiol. Rev. 59:451-480.

NRC. 2000. Nutrient Requirements of Beef Cattle: Update 2000 of 7th ed. Natl. Acad. Press, Washington, DC.

Ryden, J. C., D. C. Whitehead, D. R. Lockyer, R. B. Thompson, J. H. Skinner, and E. A. Garwood. 1987. Ammonia emission from grassland and livestock production systems in the UK. Environ. Pollut. 48:173-184.

Satter, L. D., and L. L. Slyter. 1974. Effect of ammonia concentration on rumen microbial protein production in vitro. Br. J. Nutr. 32:199-208.

Shi, Y., D. B. Parker, N. A. Cole, B. W. Auvermann, and J. E. Mehlhorn. 2001. Surface amendments to minimize ammonia emissions from beef cattle feedlots. Trans. Am. Soc. Agric. Eng. 44:677-682.

Stewart, B. A. 1970. Volatilization and nitrification of nitrogen from urine under simulated cattle feedlot conditions. Environ. Sci. Tech. 4:579-582.

USEPA. 1983. Methods for Chemical Analysis of Waters and Wastes. EPA 600/4-79-020, rev. ed. U.S. Environ. Protect. Agency, Washington, DC.

Whitehead, D. C., and N. Raistrick. 1991. Effects of some environmental factors on ammonia volatilization from simulated livestock urine applied to soil. Biol. Fertil. Soils 11:279-284. 